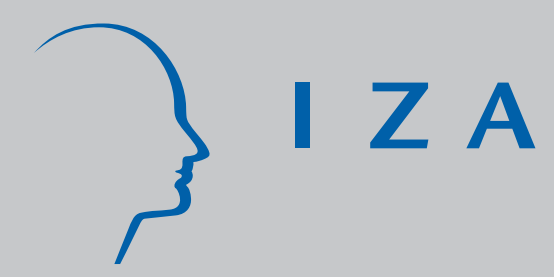

IZA DP No. 3372

The Effects of Naturalization on Immigrants'

Employment Probability (France, 1968-1999)

Denis Fougère

Mirna Safi

February 2008 


\title{
The Effects of Naturalization on Immigrants' Employment Probability (France, 1968-1999)
}

Denis Fougère

CNRS, CREST-INSEE, CEPR and IZA

Mirna Safi

OSC/Sciences-Po

and CREST-INSEE

\section{Discussion Paper No. 3372 \\ February 2008}

\author{
IZA \\ P.O. Box 7240 \\ 53072 Bonn \\ Germany
}

Phone: +49-228-3894-0

Fax: +49-228-3894-180

E-mail: iza@iza.org

\begin{abstract}
Any opinions expressed here are those of the author(s) and not those of IZA. Research published in this series may include views on policy, but the institute itself takes no institutional policy positions.

The Institute for the Study of Labor (IZA) in Bonn is a local and virtual international research center and a place of communication between science, politics and business. IZA is an independent nonprofit organization supported by Deutsche Post World Net. The center is associated with the University of Bonn and offers a stimulating research environment through its international network, workshops and conferences, data service, project support, research visits and doctoral program. IZA engages in (i) original and internationally competitive research in all fields of labor economics, (ii) development of policy concepts, and (iii) dissemination of research results and concepts to the interested public.
\end{abstract}

IZA Discussion Papers often represent preliminary work and are circulated to encourage discussion. Citation of such a paper should account for its provisional character. A revised version may be available directly from the author. 
IZA Discussion Paper No. 3372

February 2008

\title{
ABSTRACT \\ The Effects of Naturalization on Immigrants' Employment Probability (France, 1968-1999)
}

\begin{abstract}
Naturalization is usually regarded as an important sign of civic and political integration amongst immigrants, but it can also be seen as a factor of their economic integration. The aim of this study is to analyze the naturalization phenomenon in France and examine its link with the immigrants' labor force status. We use longitudinal data from the "Echantillon Démographique Permanent" (EDP) sample. The EDP is a panel dataset by which we can follow almost $1 \%$ of the French population from 1968 to 1999 through information contained in the 1968, 1975, 1982, 1990 and 1999 French census. The sample we use $(N=36,685)$ is limited to immigrants who declared themselves non-naturalized at the time they first appeared in the panel. This makes it possible for us to observe possible changes of nationality between two census dates and their potential consequences on the employment probability at the second date. In our study, the probability of naturalization between two census dates not only depends on observable individual characteristics of immigrants (country of birth, age, marital situation, occupation, human capital, etc.), but also on a number of contextual variables related to the role of the community in the assimilation process (size of the community and number of foreigners in the region of residence). We compare the differential rates of naturalization between the various ethnic groups and try to answer the following question: are there differences between the naturalized immigrant population and the immigrant population as a whole? In the second stage, we analyze the effect of naturalization on the individual employment probability by estimating a univariate probit model. To control for the potential endogeneity of the naturalization process, we also estimate a bivariate probit model. With both models, we find that naturalization has a significant positive effect on immigrants' employability and that this effect is particularly high for groups of immigrants who have a low probability of employment in the host country.
\end{abstract}

JEL Classification: F22, J15, J61

Keywords: immigration, naturalization, citizenship, employment

Corresponding author:

Denis Fougère

CREST-INSEE

15, Boulevard Gabriel Péri

92245 Malakoff Cedex

France

E-mail: fougere@ensae.fr 


\section{Introduction}

In 2004, 4.5 million immigrants (defined as people born abroad and living in France) aged 18 or above were residents of mainland France (Borrel and Durr, 2005). They accounted for 9.6\% of the total population of the same age. $41 \%$ of them have gained French nationality. ${ }^{1}$ This contrasts with the $37 \%$ posted in 1999. The change can be ascribed to the sharp increase in the number of people granted citizenship in the last few years: the figure went from 92,410 in 1995 to 128,092 in 2002, and subsequently, 144,640 in 2003, for a $13 \%$ increase over the last two years. ${ }^{2}$ Even though changes in French law on citizenship reflect certain ambiguous points in the French integration policy, France is one of the most open countries in Europe in this area (Weil, 2005, p. 63). However, law, as primordial as it may be, is not the sole factor: "immigration policy can also be measured through the practices of the civil servants who implement it" (Spire, 2005, p. 11) and, we might add, in the way immigrants experience and perceive it. Why is it that, even though a large number of foreigners having settled in France seek French citizenship, only some of them are granted it? Is gaining citizenship in one's host country the culmination of the integration process, or only an important stage, which will lower certain discriminatory barriers and make it possible for immigrants to fully take part in the citizens' community in the host country?

A large portion of socio-demographic literature on naturalization has focused on the immigrants' viewpoint, or more accurately, their propensity to becoming citizens of the host country. For example, Portes and Mozo (1985) emphasized the importance of socio-economic variables (income, profession, housing ownership). Barkan and Khokhlov (1980), meanwhile, stressed cultural variables, such as proficiency in the language of the host country. Other research has sought to take into account background variables, in particular the size of the community of origin, its geographic establishment in the host country and developments in legislation making it possible to gain citizenship in the country (Portes, 1987; Yang, 1994). ${ }^{3}$ As for economists, they have dwelt more on how gaining citizenship in the host country impacts the individual wage (Chiswick, 1978; Bratsberg, Ragan and Nasir, 2002) or employment in immigrant populations (DeVoretz and Pivnenko, 2004; Bevelander and Veenman, 2006). At the same time, our study attempts to identify the factors that affect the propensity of gaining citizenship and measure the effects the latter can have on the probability of being employed.

There are two such effects. First, naturalization helps immigrants enter professions previously off limits to them (particularly in civil service or the self-employed or liberal sector; Math and Spire,

\footnotetext{
1 For the sake of comparison, in 2004, the United States had a higher percentage of immigrants aged 18 and over, accounting for $14.5 \%$ of the total population of the same age; however, within that immigrant population, the percentage of people having gained American citizenship was remarkably identical to the estimated percentage in France, at $40.6 \%$ (for exact figures, readers may check the Web site: http://www.census.gov/population/socdemo/foreign/ppl-176/tab01-1.pdf). 2 Looking only at the number of people granted citizenship by decree or declaration (see Section 2), the numbers are 61,884 in 1995, 95,552 in 2002 and 110,511 in 2003, for an increase of 19.4\% over the course of 2003 (the figures are provided on INSEE's Web site, at: http://www.insee.fr/fr/ffc/chifcle_fiche.asp?ref id=NATCCI02122\&tab_id=425\&souspop=4).

${ }^{3}$ An already dated summary of the work carried out in the 1970s and 1980s can be found in De Sipio's article (1987).
} 
1999). Secondly, it does away with some of the discriminatory obstacles that arise during the recruitment process. However, it is difficult to pinpoint the direct effects of naturalization: the immigrants who gain French citizenship are not a sample randomly drawn from amongst the immigrants living on French soil. They differ from others in observable characteristics (education, for instance), but also through other characteristics, which are not observable. Yet those characteristics also affect their probability of finding a job, and this needs to be taken into account.

The aim of our study is to analyze the naturalization phenomenon in France and examine its link with the immigrants' labor force status. We use longitudinal data from the "Echantillon Démographique Permanent" (EDP) sample. The EDP is a panel dataset by which we can follow almost $1 \%$ of the French population from 1968 to 1999 through information contained in the 1968, 1975, 1982, 1990 and 1999 French censuses. The sample we use $(N=36,685)$ is limited to immigrants who declared themselves non-naturalized at the time they first appeared in the panel. This makes it possible for us to observe possible changes of nationality between two census dates and their potential consequences on the employment probability at the second date. In our study, the probability of naturalization between two census dates not only depends on observable individual characteristics of immigrants (country of birth, age, marital situation, occupation, human capital, etc.), but also on a number of contextual variables related to the role of the community in the assimilation process (size of the community and number of foreigners in the region of residence). We compare the differential rates of naturalization between the various ethnic groups and try to answer the following question: are there differences between the naturalized immigrant population and the immigrant population as a whole? In the second stage, we analyze the effect of naturalization on the individual employment probability by estimating a univariate probit model. To control for the potential endogeneity of the naturalization process, we also estimate a bivariate probit model. With both models, we find that naturalization has a significant positive effect on immigrants' employability and that this effect is particularly high for groups of immigrants who have a low probability of employment in the host country.

The next section presents the data we use. Section 3 recalls the ways through which immigrants can gain the French nationality. Section 4 describes the trends and the structure of naturalizations in France between 1968 and 1999. Section 5 examines the determinants of naturalization, and section 6 presents estimates of the effect of naturalization on the individual probability to be employed. Section 7 concludes.

\section{The Data}

The Echantillon Démographique Permanent (EDP) makes it possible to track individuals using the information gathered during the 1968, 1975, 1982, 1990 and 1999 censuses. At each census, every 
individual residing in France declares his or her nationality. It is therefore possible to identify the immigrants who have gained French citizenship between two censuses. Thereby, we built a sample that includes all the individuals present at least in two successive censuses.

The EDP panel is an extensive longitudinal dataset, based on individual data from French censuses, using birth date as the main criterion. The data registry was created in 1967 and now includes data from the 1968, 1975, 1982, 1990 and 1999 censuses. The EDP includes individuals born on certain days of the year (four out of 365 days, or around 1\% of the population) and for whom a census form or civil status certificate issued upon one of the major demographic events in an individual's life (birth, marriage, death, childbirth, etc.) is available. Every year, the individuals born on the four reference days are added to those already in the sample. As regards immigrants, they appear in the EDP as soon as they are identified, or as soon as one of their civil status certificates is found. In addition, an immigrant may disappear from the EDP due to migration outside France or death, like any other individual in the sample.

The primarily demographic nature of the census data is such that the EDP does not provide access to information that is particularly useful for studies on immigration. One of the main missing variables is the individual degree of proficiency in the French language, which is known to play a primordial role in immigrant naturalization.

The analyzed sample is restricted to individuals having declared themselves as foreigners born abroad when they first appeared in the EDP. In order for an individual to give rise to an observation, he or she must be present (or more specifically, identified in the census) in two consecutive censuses. This means that we eliminate all chains containing the following pattern: (present in $t$, absent in $t+1$ ), (absent in $t$, present in $t+1$ ), (absent in $t$, absent in $t+1$ ), where $t$ is the date of one of the censuses (1968, 1975, 1982, 1990), and $t+1$ is the date of the following census. This means that an individual can give rise to four observations at most of the following kind: present in $t$, present in $t+1$ ). In this case, his citizenship may evolve in one of three ways:

- foreigner in $t$, foreigner in $t+1$,

- foreigner in $t$, French in $t+1$,

- French in $t$, French in $t+1$.

Individuals on whom the third observation is made are discarded, considering that what we wish to detect is the transition from foreigner to French citizen. If an individual is a foreigner in 1968 and a foreigner in 1975, he gives rise to an observation with the variable "naturalization" taking the value 0 in this period. On the other hand, if the person is a foreigner in 1968 and became French in 1975, he gives rise to an observation with the variable "naturalization" taking the value 1 . An individual having followed the "absent in 1968, foreigner in 1975, foreigner in 1982, French in 1990, French in 1999" path gives rise to two types of observations: 
- the first observation is characterized by a value of 0 for the "naturalization" variable in the second inter-census period (1975-1982);

- the second observation is characterized by a value of 1 for the "naturalization" variable in the third inter-census period (1982-1990).

An individual present on all five census dates who remains a foreigner throughout the period will give rise to four observations, with the "naturalization" variable having the value 0 during each of the four waves.

As a result of the sample design described above, all naturalizations not specifically identifiable as occurring between two successive censuses are eliminated. For instance, a foreigner in $t$, absent in $t+l$ and naturalized in $t+2$ cannot be taken into account in the analysis. To be able to include this individual, assumptions would have to be made about her naturalization date: was she naturalized prior to her departure (between $t$ and $t+l$ ) or after her return (between $t+l$ and $t+2$ )?

The analyzed sample described also excludes observations missing from the second census. Incorporating them into the analysis would raise a real issue, as there potentially exists a dual causal relationship between naturalization and the individual's migratory path: a foreigner may leave French soil before even seeking French citizenship, in which case the departure prevents possible citizenship from being noted; however, she may also leave the country because she failed to gain citizenship. A complementary statistical analysis shows that the probability of an individual's exiting the sample between two successive censuses (defined as the probability of being present during the first census, but absent for the second) is significantly higher for people hailing from Algeria or Morocco, those aged 25 to 35, men, single people, managers, office workers and intermediate professions. It is greater amongst people with a higher education as opposed to those who have earned only a primary education certificate (certificat d'études primaires) or certificate of first-degree education (BEPC). As the probabilities of naturalization and employment both increase with education and professional qualifications, it is possible that our findings somewhat overestimate the positive effect of naturalization on employment. To confirm that conjecture, we would need more extensive information about the migratory and professional paths of foreigners having resided in France.

\section{Ways for Gaining French Nationality}

French citizenship is granted at birth, based either on parentage (having at least one parent of French nationality) or place of birth (by virtue of the right of soil, which applies to children born in France with at least one parent born in France). When an individual becomes French after birth, this is referred to as gaining French nationality. There are three methods for gaining French nationality (Weil, 2002): 
- Gaining French nationality by operation of law, by virtue of birth and residence in France. This method is based on the idea that being born and residing in France are de facto conditions for integrating young foreigners, giving them the right to become French. With the 1993 Law, an additional condition was introduced: "expressing the wish" to be French, which assumes voluntary action on the part of a young foreigner bearing witness to her desire to become French. This process was revoked in 1998; from that year on, young foreigners born in France become French by operation of law at the age of 18 .

- Gaining French nationality by declaration: this applies in particular to individuals who marry a person of French nationality.

- Gaining French nationality by decree: in this case, it is decided by the public authorities that French nationality shall be granted at the request of a foreigner and provided certain conditions.

Over the last ten years, the average annual number of individuals gaining French nationality was 125,000 , including all methods, with $20 \%$ by declaration and $50 \%$ by decree. ${ }^{4}$

Immigrants can become French by decree (meaning by naturalization), as is the case the majority of the time, or by declaration, following marriage with a spouse of French nationality. ${ }^{5}$ Yet the two methods clearly proceed from different rationale, and also have different impacts on employment paths. As inter-ethnic marriages and their effects on social integration require specific attention, our study is dedicated to analyzing nationality when gained by decree. It is impossible to identify unfailingly each instance in which nationality was gained by declaration in the EDP data. However, information from marriage records, where the spouse's nationality appears, makes it nonetheless possible to discard the cases in which an inter-ethnic marriage and successful citizenship application occurred during the same inter-census period.

Focusing our analysis on citizenship gained by decree, we left out those cases involving inter-ethnic marriage with citizenship gained during the same inter-census period. Clearly, the method is imprecise: it is possible that, between two censuses, an immigrant may gain nationality by decree, then marry a person of French nationality. This procedure eliminates $20.4 \%$ of naturalizations observed in the data.

Lastly, as our study aims to analyze the interaction between naturalization and employment, the sample is limited to individuals between ages 18 and 55, who were neither students nor engaged in the

\footnotetext{
${ }^{4}$ We have no information about applications for naturalization and, in particular, the differences in application rates by country of origin. Evaluating these rates is a very difficult process, as this requires observing not only the breakdown in naturalization applications by country of origin, but also the number of foreigners who can be "assumed" to fulfill the naturalization requirements for each country of origin.

${ }^{5}$ Aside from the time between 1993 and 1997, those born on French soil are automatically granted French citizenship, the only condition being that they reside in France. This means that it is impossible to analyze every form of gaining French nationality, given that the conditions for this, as defined in this approach, differ greatly depending on whether an individual is born in France or abroad.
} 
military at the time. Given those restrictions, the sample was reduced to 36,685 observations (corresponding to 21,779 individuals). The countries involved, covering Western Europe (other than Spain, Italy and Portugal), Southeast Asia, Sub-Saharan Africa and Eastern Europe, were grouped into extended geographic zones so as to achieve strata of sufficient size.

In certain birth countries, there are few immigrants residing in France. Therefore, analysis by country of origin can be performed only for countries with sufficient representation in the sample: Spain, Italy, Portugal, Algeria, Morocco, Tunisia and Turkey. Western Europe (excluding Spain, Italy and Portugal), Southeast Asia (Cambodia, Laos and Vietnam), Sub-Saharan Africa and Eastern Europe were also brought into the analysis, but without distinction between countries of origin (Table 1).

Table 1

Number of observations by country or group of countries

of origin

\begin{tabular}{|l|r|r|}
\hline Country of origin & Number of observations & Percentage \\
\hline Portugal & 9670 & 26.36 \\
\hline Algeria & 6577 & 17.93 \\
\hline Italy & 6227 & 16.97 \\
\hline Spain & 4571 & 12.46 \\
\hline Tunisia & 2124 & 5.79 \\
\hline Other countries from Western & 1949 & 5.31 \\
Europe & & 4.14 \\
\hline Eastern Europe & 1518 & 3.45 \\
\hline Turkey & 1266 & 2.88 \\
\hline Morocco & 1056 & 2.42 \\
\hline South-East Asia & 888 & 2.29 \\
\hline Sub-Saharan Africa & 839 & $\mathbf{1 0 0}$ \\
\hline Total & $\mathbf{3 6 \mathbf { 6 8 5 }}$ & \\
\hline
\end{tabular}

Source : Échantillon Démographique Permanent, Insee (1968-1999)

Foreigners of European origin are, overall, the largest in number. However, their relative numbers have consistently declined over time, between 1968 and 1999 (Graph 1a). For example, Italians accounted for $29.7 \%$ of immigrants in the sample in 1968, but only $8.4 \%$ in 1999 . Foreigners from Tunisia, Morocco, Turkey, Southeast Asia and Sub-Saharan Africa, in contrast, saw their percentages increase very significantly (Graph $1 b$ ). For instance, Tunisians accounted for $3.8 \%$ of immigrants in the sample in 1968, as compared to 6.9\% in 1999. 


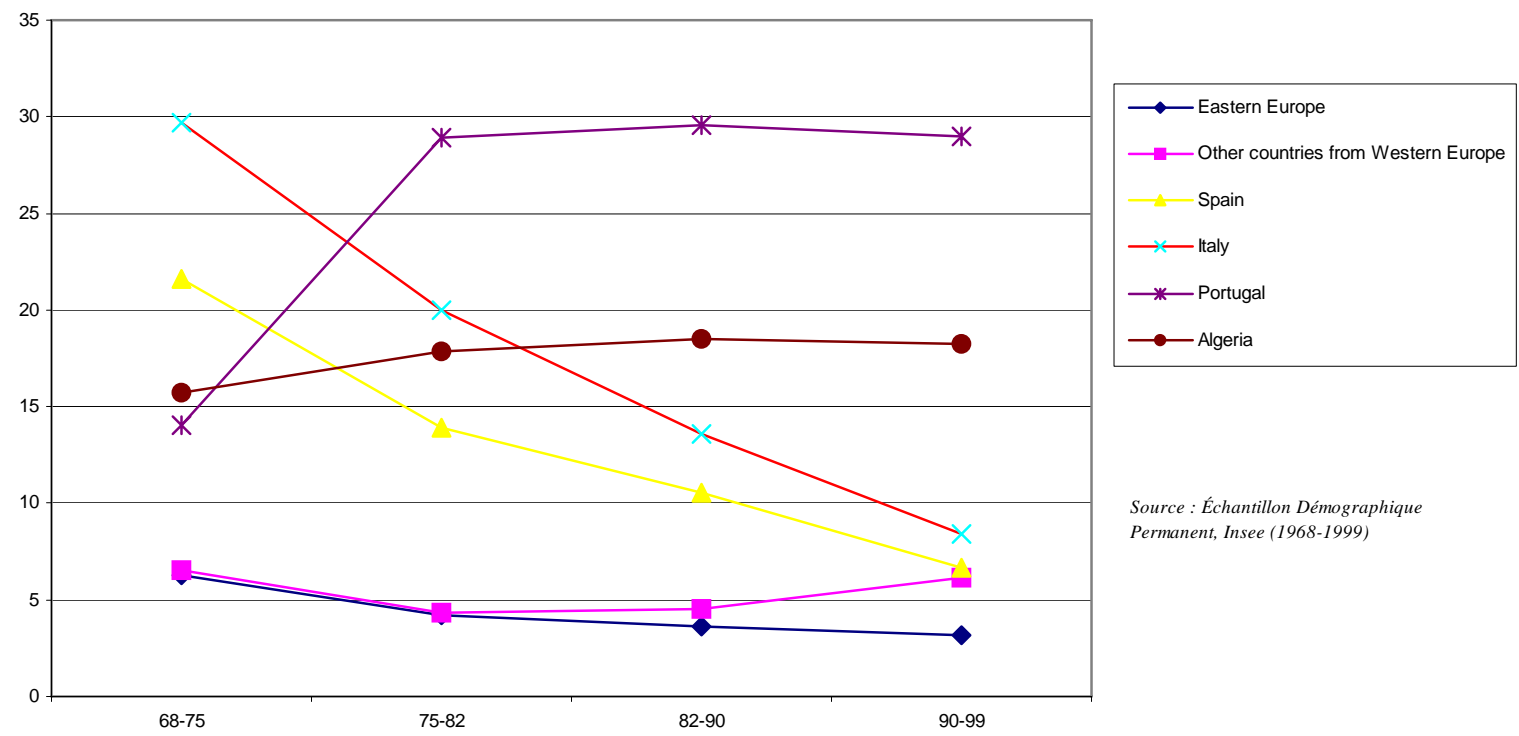

Graph 1b . Origins of immigrants, in percent (increasing fractions)

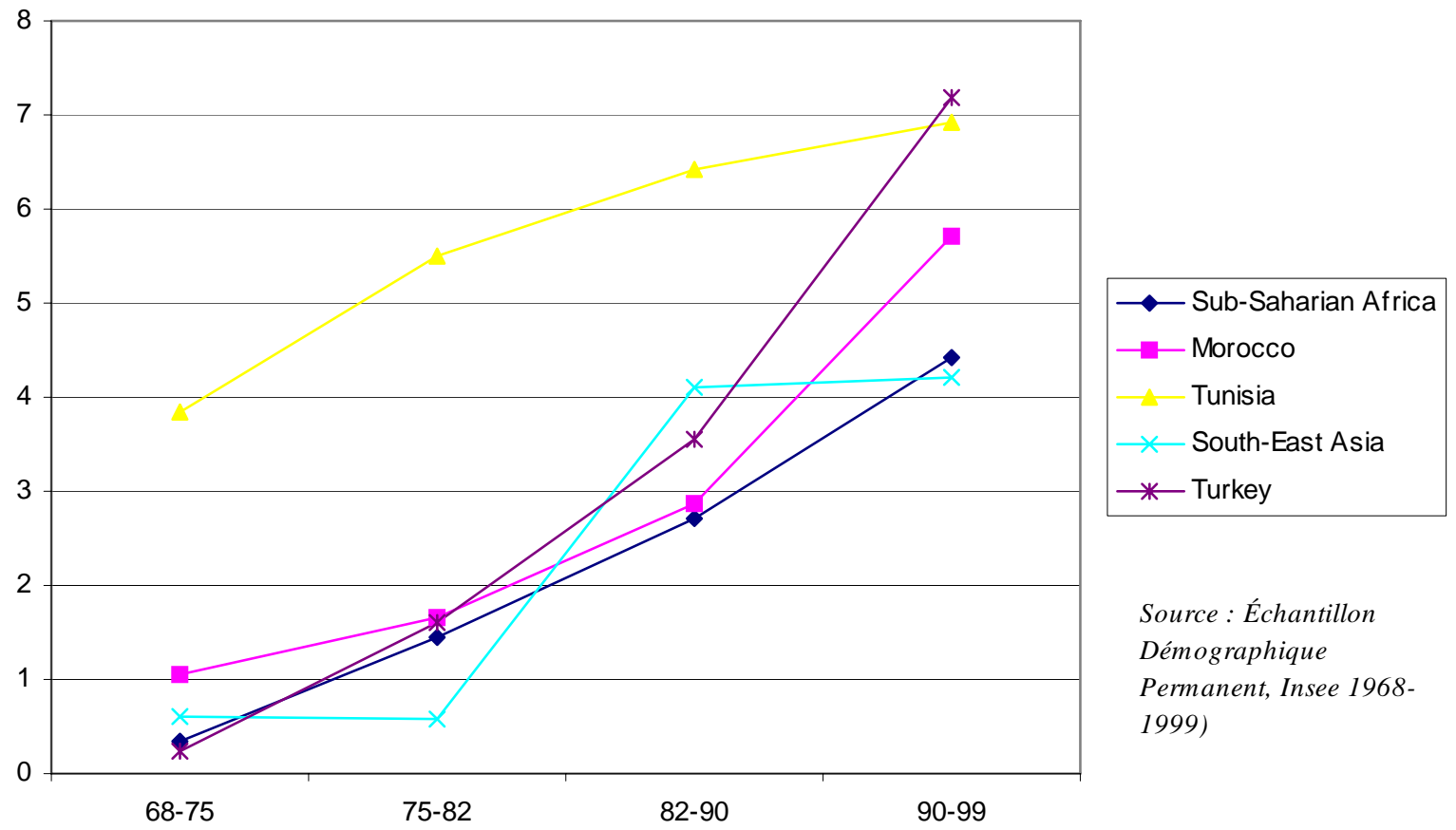

\section{Naturalization in France between 1968 and 1999: Trends and Structure}

For many individuals, gaining nationality is seen as the "final” step in an immigrant's integration process. Because of this, it is often seen from the individual's viewpoint, rather than from that of the host society. It then becomes associated with successful assimilation, and reflected by a desire to engage as a citizen and individual. In other cases, it is no more than an instrumental computation of the benefits that gaining citizenship of the host country carries for the foreigner embarking on the process. However, naturalization can also be seen as the result of the interaction between an 
individual's decision (that of the foreigner applying for naturalization) and an entire society's attitude toward immigration, in particular as seen in the workings of its administrative institutions (Spire, 2005). From that angle, everything works out as though gaining nationality were the result of a supply and demand relationship, the demand (or self-selection) consisting of immigrants having fulfilled a number of conditions, and the supply, or more accurately, selection procedure, which culminates in the decision to naturalize by decree. The EDP data only reflect those instances in which the procedure has had a positive outcome and naturalization has been granted. They make no distinction between the cases in which no request for naturalization was sought, and those in which it was sought, but not granted. A low naturalization rate can be the result of infrequent demand or multiple rejections on the part of the administration. The longitudinal data from the EDP are used here not to show the selective or self-selective behaviors that determine the outcome of the naturalization process, but rather to shed light on the individual characteristics correlated with gaining citizenship.

Over the 1968-1999 period, 11.1\% of immigrants present in two consecutive censuses gained French citizenship. The naturalization rate dropped off slightly between 1975 and 1982, before rising steadily (Graph 2).

\footnotetext{
Graph 2

Numbers of naturalizations

observed in the sample
}

Démographique

Permanent, Insee (19681999)

Interpretation : amongst the 4,094 naturalizations that are observed in our sample, 953 have occurred between 1968 and 1975

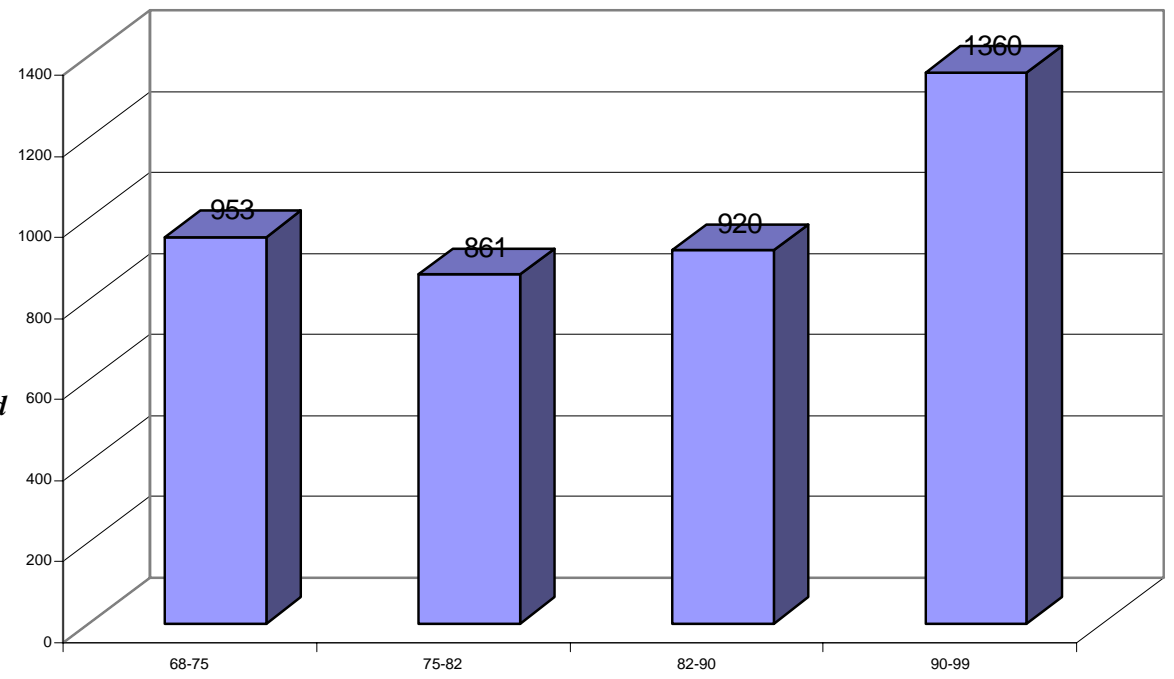

The average naturalization rate differs significantly depending on country of origin (Table 2). Southeast Asia and Sub-Saharan Africa are associated with the highest naturalization rates. In contrast, immigrants hailing from Algeria, Turkey and Portugal are the least likely to be naturalized. The aforementioned rates show very different trends over the same period, however. For instance, whereas 
the Algerians' naturalization rate was particularly low early in the period - this probably being due to France's colonial past with Algeria (Sayad, 1982) - it posted very sharp growth starting from the 1980s. Though their trends have been far less consistent, Moroccans and, to a lesser extent, Tunisians, show much higher naturalization rates than Algerians. ${ }^{6}$ Among European countries, Portugal is the exception: Portuguese immigrants are the only Europeans whose naturalization rate increased during the second half of the reference period, probably because, until 1982, Portugal prohibited dual nationality to its citizens. In contrast, the naturalization rate amongst Spanish and Italian immigrants, like that of immigrants from other countries in Western Europe, continually declined between 1968 and 1999. In their case, the cause can be ascribed more to demand: citizens from those countries apply less and less frequently for naturalization, particularly considering the backdrop of the European Union, which significantly cuts down on the attractiveness of gaining citizenship in the host country, when the said country is a Union Member State.

Table 2

Naturalization rates according to the country or group of countries of origin

\begin{tabular}{|c|c|c|c|c|c|}
\hline Country of origin & $\begin{array}{l}\text { Naturalization } \\
\text { rate } \\
\text { between } 1968 \\
\text { and } 1999 \\
\end{array}$ & $\begin{array}{c}\text { Naturalization } \\
\text { rate } \\
\text { between } 1968 \\
\text { and } 1975 \\
\end{array}$ & $\begin{array}{l}\text { Naturalization } \\
\text { rate } \\
\text { between } 1975 \\
\text { and } 1982 \\
\end{array}$ & $\begin{array}{c}\text { Naturalization } \\
\text { rate } \\
\text { between } 1982 \\
\text { and } 1990 \\
\end{array}$ & $\begin{array}{l}\text { Naturalization } \\
\text { rate } \\
\text { between } 1990 \\
\text { and } 1999 \\
\end{array}$ \\
\hline South-East Asia & 41.89 & 38.64 & 65.22 & 36.36 & 45.02 \\
\hline Sub-Saharan Africa & 32.9 & $8.7 *$ & 26.32 & 36.54 & 34.04 \\
\hline Morocco & 23.67 & 40.26 & 25,0 & 11.31 & 27.12 \\
\hline Eastern Europe & 23.12 & 25.76 & 17.14 & 21.84 & 28.08 \\
\hline Tunisia & 14.69 & 28.87 & 9.2 & 7.73 & 19.28 \\
\hline Spain & 12.54 & 15.44 & 14.63 & 9.45 & 6.27 \\
\hline Italy & 10.36 & 12.73 & 11.54 & 7.84 & 5.56 \\
\hline $\begin{array}{l}\text { Other countries } \\
\text { from Western Europe }\end{array}$ & 9.65 & 17.72 & 9.8 & 7.78 & 4.78 \\
\hline Turkey & 7.5 & $38.89 *$ & 1.99 & 4.46 & 9.35 \\
\hline Algeria & 6.8 & 3.64 & 3.7 & 4.19 & 14.86 \\
\hline Portugal & 6.05 & 4,0 & 5.29 & 6.66 & 6.88 \\
\hline Total & 11.11 & 12.87 & 9.18 & 9.32 & 13.55 \\
\hline
\end{tabular}

Source : Échantillon Démographique Permanent, Insee (1968-1999)

Sample : Individuals who have declared to be foreigners and to have between 18 and 55 years old at the first interview, and who are respondents at two successive interviews (i.e. censuses).

Interpretation : $32.9 \%$ of persons who come from Sub-Saharan Africa have been naturalized between 1968 and 1999. This proportion is equal to $26.3 \%$ when we consider only the persons with the same national origin who have declared to be foreigners in 1975 and who are respondents in 1982

* small sample size

\footnotetext{
${ }^{6}$ Immigrants from these two countries have been some of the most likely to request French nationality since 1990 (Belbah and Chatou, 2001).
} 
From 1968 to 1999, female naturalization rates were generally higher than those of males. For instance, whereas women accounted for $41 \%$ of the total sample, they contributed $45 \%$ of the subsample of foreigners having gained French nationality (Graph 3). The gap between men and women is not the same for all nationalities; for example, women of Algerian nationality and those from Southeast Asian countries were more likely to seek and gain French nationality than their male counterparts, unlike women from Turkey and Morocco.

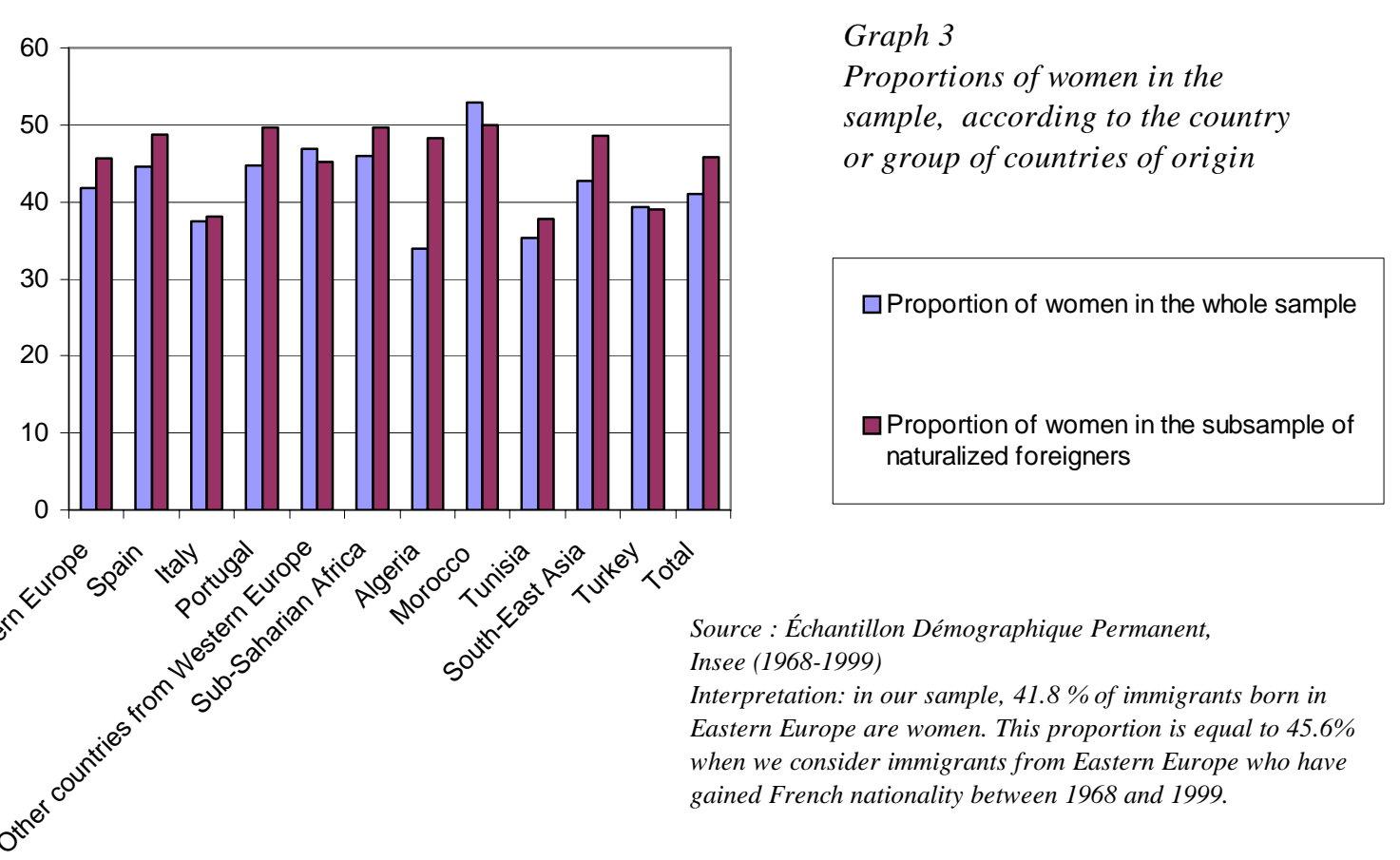

Age also seems to play a part in gaining French nationality (Graph 4). Immigrants aged 18 to 45 are more likely to become French than those above age 46. This is the result of both the demographic rationale presiding over naturalization decisions since the late $19^{\text {th }}$ century (Spire, 2005) and employers' requirements in terms of hiring. 


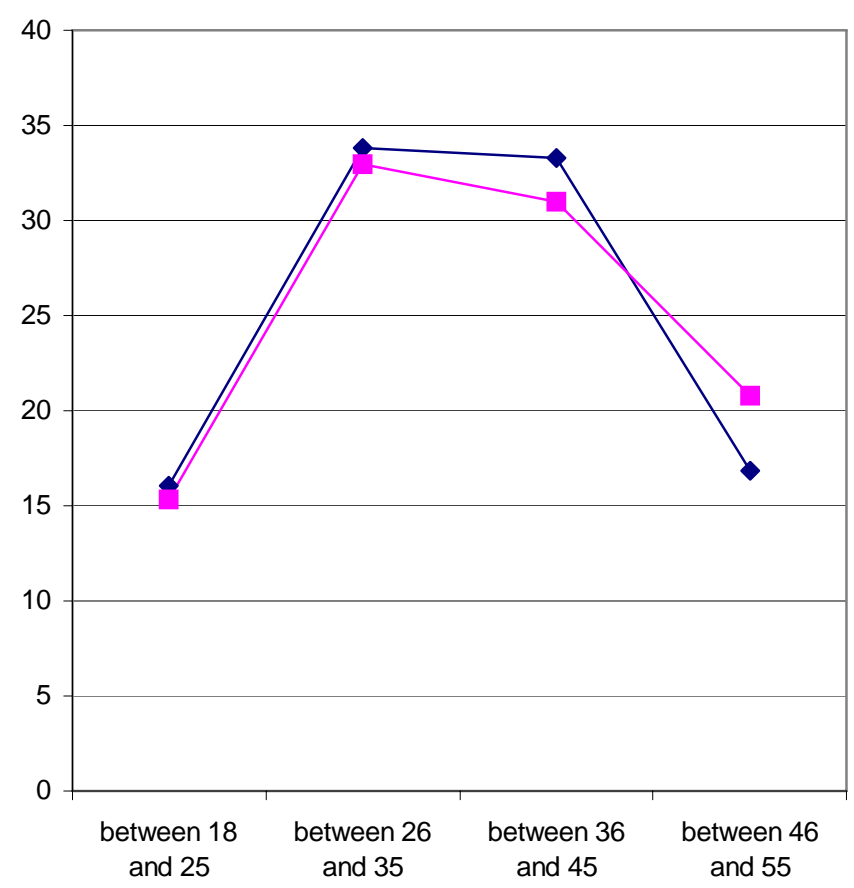

\section{Graph 4}

Immigrants' ages, in the whole sample and in the subsample of those having gained French nationality

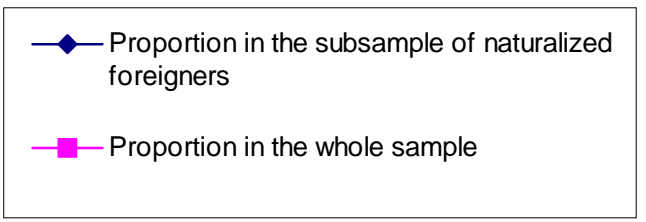

Source : Échantillon Démographique Permanent, Insee (1968-1999)

Interpretation : $33.81 \%$ of immigrants having gained French nationality between two successive censuses were between 26 and 35 years old at the date of the first census, while the proportion of those between 26 and 35 years old in the whole sample is equal to $32.95 \%$

In theory, the only formal requirement placed on those wishing to apply for naturalization is residence in France for a specific minimum duration. However, as several studies show (Weil, 2002; Spire, 2005), the naturalization process also depends in part on labor requirements, under which a balance is sought between the interests of firms and those of employees hailing from the host country. Such labor considerations are strongly correlated with the economic situation: during times of economic recession, the government and the administration tend to favor domestic labor. ${ }^{7}$

A complementary descriptive analysis shows that the individual's socio-professional category has a very significant effect on his or her probability of being naturalized. Overall, production workers and the non-employed, who account for the majority of the immigrant population, gain French nationality less frequently than managers, intermediate professions and office workers. The intensity of the selection (or self-selection) process by profession, however, appears to depend on country of origin: it is lower amongst immigrants from countries in Southern Europe (Spain, Italy, Portugal) and other Western European countries, but higher amongst immigrants from North Africa. Turkish production workers are, along with those from Western Europe, the only immigrants who are slightly overrepresented in the sub-sample of naturalized foreigners. Lastly, craftsmen, merchants and company leaders are clearly over-represented amongst immigrants from Southeast Asia, Tunisia and Turkey.

\footnotetext{
7 Graph 2 shows that the number of naturalized individuals noted saw a decline between 1975 and 1982, when employment began to rise sharply.
} 


\section{The Determinants of Naturalization}

In order to take into account jointly all of the factors possibly impacting successful application for French nationality, a statistical model must be estimated. There are two types of factors: individual socio-demographic characteristics and contextual data. Some of the characteristics determining whether an individual does or does not gain French nationality include: country of birth, gender, age, marital status, socio-professional category, education, activity status and size of place of residence. ${ }^{8}$

Contextual variables include the size of the community of origin in the place of residence and the concentration of the immigrant population in this place. Several studies show that the size of the community of origin influences the naturalization process (Portes, 1987; Yang, 1994). This effect needs to be balanced out with the concept of community network and with the impact that this network can have on individual integration processes. The community network can ease the arrival and settlement processes for newcomers, as well as their access to employment, housing and information (in particular administrative information regarding naturalization). That being said, it is difficult to predict the actual influence of the size of the community of origin.

The literature contains two competing hypotheses. Some believe that the probability of naturalization declines when the community of origin's relative size is higher. In general, the claims used to back this assertion call upon the concept of the community's "self-sufficiency". When that self-sufficiency is great enough, it can offer the newcomer an extensive network of connections, making it easier for him to find housing and employment; in that setting, gaining French nationality would not be as attractive to him. In addition, from a more symbolic standpoint, the community's size could limit the feeling of belonging to the host society, insofar as it strengthens the ties with the newcomer's compatriots and attachment to the culture of the country of origin. In summary, this claim emphasizes naturalization as something instrumental. However, the hypothesis that there is a negative relationship between a community's relative size and the desire to be naturalized is challenged by other analysts, who believe, to the contrary, that a large community can have a positive impact on its members' socioprofessional assimilation and, thereby, an indirect positive effect on their naturalization (Portes, 1995). According to that hypothesis' proponents, a larger community eases the spread of information about administrative paperwork and procedures. Unlike those who advocate the previous assertion, they underscore the "naturalization supply" or, in other words, the selection procedure that precedes all decisions to grant nationality. To take into account the relative size of the community of origin, the percentage of immigrants by origin and by region of residence ${ }^{9}$ has been included amongst the factors likely to foster successful application for French nationality.

\footnotetext{
8 The value of each of these variables, with the exception of country of birth and gender, can vary from one inter-census period to the next. Where no information is available about the value of one covariate at the exact time of naturalization, its value at the start of the inter-census period is used.

9 This variable was computed using EDP data. In order to limit imprecision due to the low number of foreigners in certain regions, the rates were calculated by region of origin, rather than country of birth. For instance, a Moroccan immigrant
} 
However, the number of immigrants can have yet another effect: it determines, at least indirectly so, the length of the queue for those applying for nationality. The length of the "waiting line” can, in turn, slow down the naturalization process and lower chances of gaining nationality between two census dates. In order to illustrate this phenomenon, two variables were added to the list of factors likely to affect naturalization: first, the number of foreigners (implicitly considered as potential candidates for naturalization) residing in the same local administrative unit at the time of the census, ${ }^{10}$ and secondly, for more detailed analysis, the number of foreigners of the same descent residing in the same local administrative unit at the time of the census. It is expected that the impact of these two variables on the probability of naturalization will be negative: the longer the queue, the lower the probability of gaining nationality between the two dates.

Lastly, in order to reflect the possible impact of the economic environment, we have also incorporated a dummy variable indicating the inter-census period (1968-1975, 1975-1982, 1982-1990, or 19901999) into the analysis. The effects of all these covariates on the naturalization probability are estimated by using a univariate probit model (see Table A, Appendices, and especially the two last columns of this Table).

Results show that the country of origin has a strong impact on the probability of naturalization between two consecutive censuses. Immigrants from Southeast Asia, Sub-Saharan Africa and, to a lesser extent, Eastern Europe, are more likely to be naturalized than Moroccans. Immigrants from Portugal, Algeria, Italy and Turkey are the least likely to be naturalized. In addition, women are more likely to be naturalized than men. ${ }^{11}$ The birth country ranking by impact on the probability of naturalization is almost the same for men and women, but the gaps between Turkey, Portugal and Algeria, on one side, and Sub-Saharan Africa and Southeast Asia on the other, are greater amongst women than amongst men (Graph 5).

\footnotetext{
who lives in the Aquitaine region will be assigned to the percentage of North African immigrants living in the region. That choice implicitly assumes that the community network includes all foreigners from the same geographical zone.

10 The groups of foreigners belonging to a nationality or group of nationalities are computed by department, as applications for naturalization must be filed with the département prefecture. In 1968 and 1975, as the relevant census data have not yet become available to us, we estimated the numbers based on the EDP, applying the survey rate of $1.09 \%$. For 1982 and 1990, we were able to secure the census data for the said years.

${ }^{11}$ A similar result is obtained by Constant, Gataullina and Zimmermann (2008) for Turkish and ex-Yugoslav immigrants in Germany.
} 


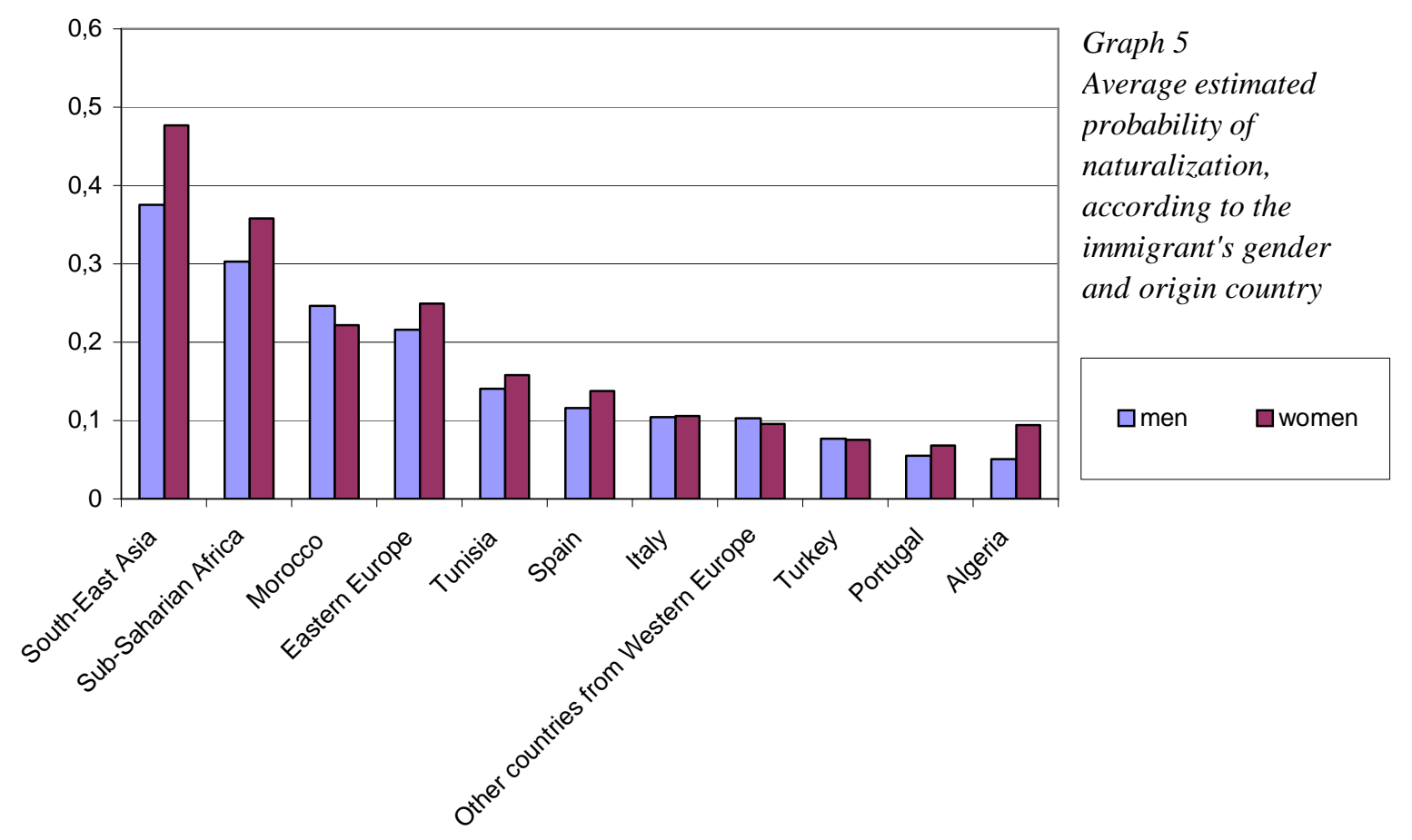

Socio-professional category and educational attainment also have a highly significant effect on the probability of naturalization (Graphs 6 and 7); this illustrates the type of selection and, perhaps, selfselection, at work in the naturalization process. Being non-employed reduces the probability of naturalization, whatever the degree of educational attainment. Production workers also appear at a disadvantage. Lastly, selection by human capital variables seems to play a less prominent role for women than for men: an immigrant manager is 2.7 times more likely to be naturalized than an immigrant production worker, while the probability of naturalization for a female immigrant manager is 1.6 times higher than that of a female immigrant production worker. Unlike inactivity, unemployment does not hinder naturalization for immigrant women.

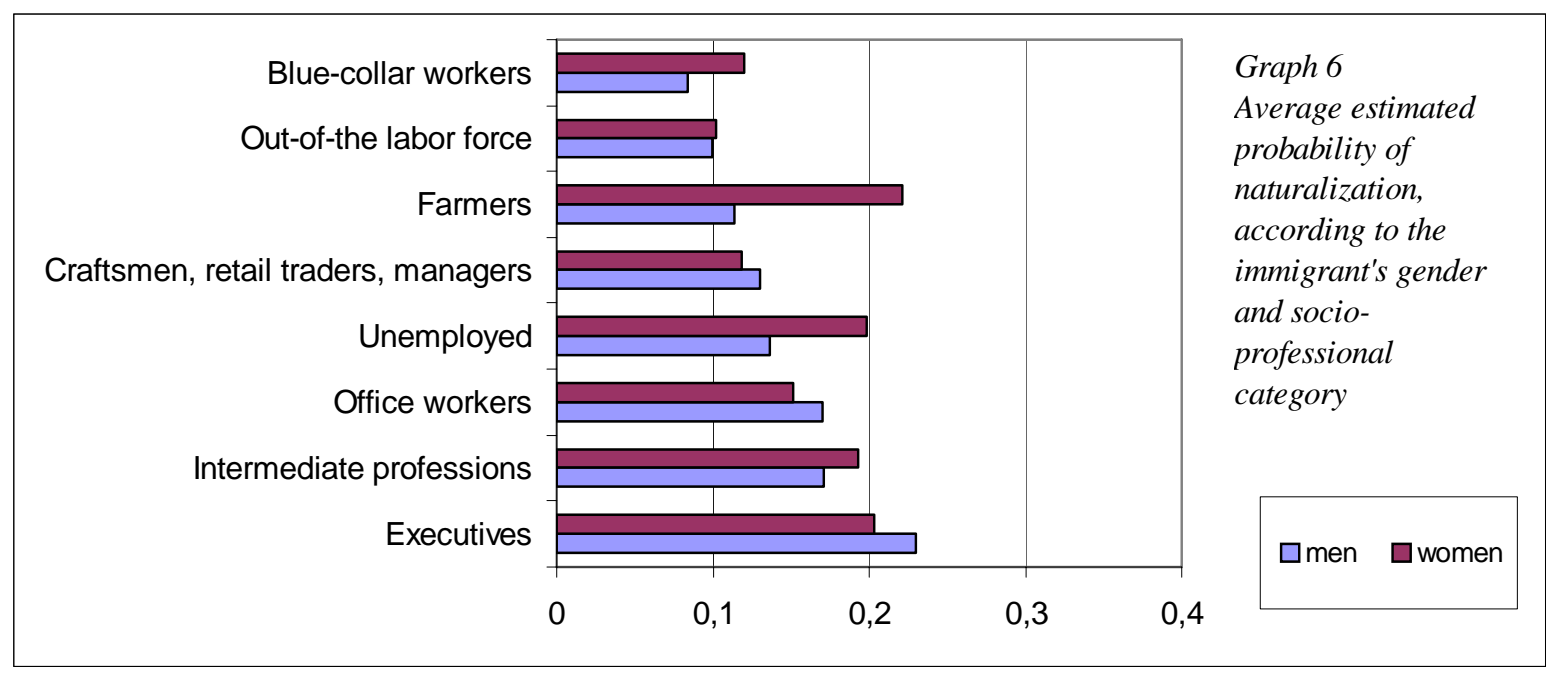




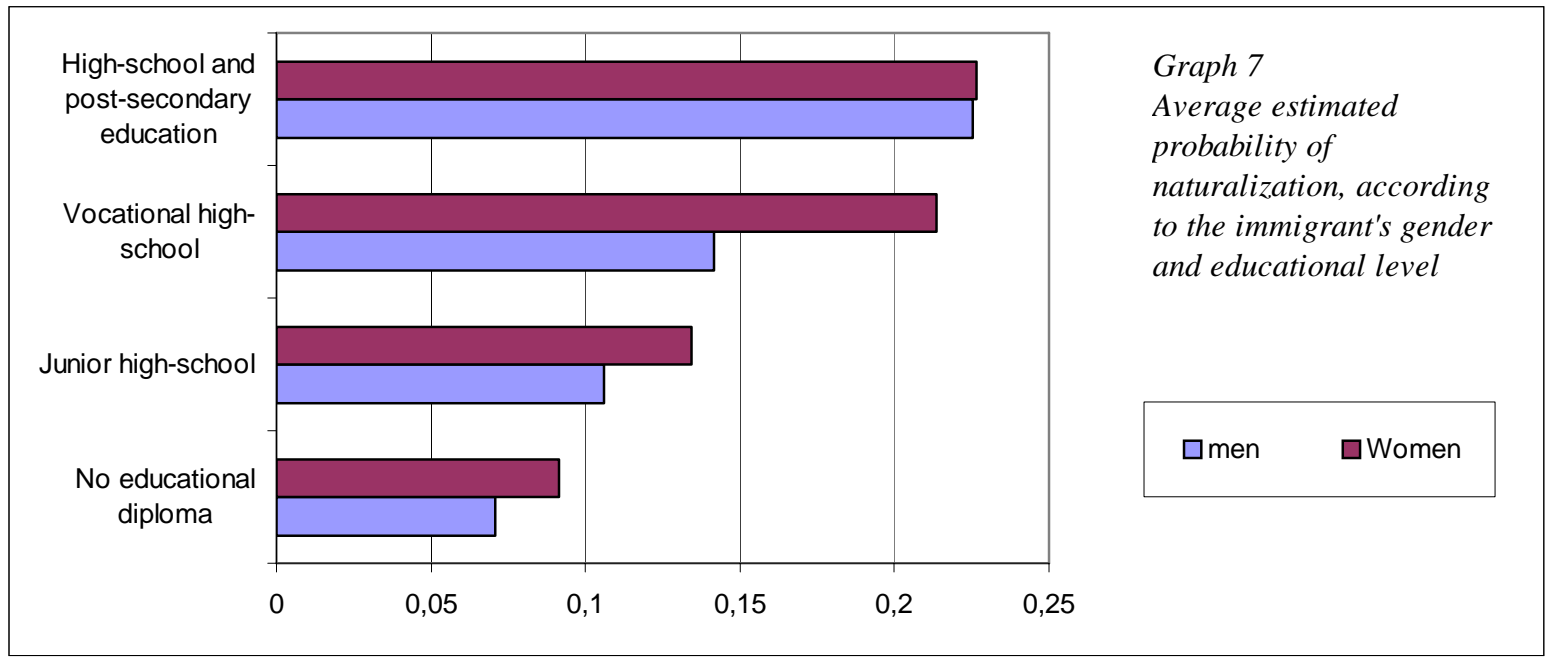

The influence of marital status is different for men and women. Married men are more likely to gain French nationality than single men, whereas the opposite is true for women. Immigrants residing in towns with fewer than 20,000 inhabitants are more likely to gain French nationality.

The relative size of the community of the country of origin has a positive impact on the probability of naturalization, and is slightly higher for men than for women. This confirms the hypothesis stated above on the role of community networks in the naturalization process. As expected, the length of the potential queue, as measured by the number of foreigners (of the same or different origin) in the local administrative unit, on the other hand, has a negative effect that seems unconnected to the country of origin.

\section{The Effect of Naturalization on the Individual Probability of Being Employed}

Whereas gaining the nationality of the host country is often presented as the final step in an immigrant's integration process, questions can be raised as to whether it is not more an intermediate step, one that strengthens integration, in particular in its socio-economic aspect. It can be assumed that naturalization affects immigrants' status on the labor market and, in particular, their ability to secure a job, due to a range of reasons. When an immigrant gains French nationality, the range of jobs available to him opens up, to include in particular all of the jobs requiring French nationality (Math and Spire, 1999). At the same time, it can be assumed that the immigrant can more easily circumvent discriminatory situations during the hiring process. Several empirical studies have revealed such forms of discrimination. Conducted more frequently in the United States than in France, they are often based on field experiments. They sometimes use job applicants' first names to denote ethnic origin (Bertrand and Mullainathan, 2004). In France, Amadieu (2004) has recently published the results of a field 
experiment which shows that, at a given level of education and of employment experience, applicants of North African origin are less likely to be called in for an interview (and, ultimately, to be hired) than the others.

Many studies today use individual wages to measure the effect of gaining nationality on immigrants' socioeconomic integration. This is true, for instance, of the pioneering research carried out by Chiswick (1978) which shows that, provided equal socioeconomic characteristics, naturalized immigrants earn an average of $15 \%$ more income than non-naturalized foreigners. Chiswick minimizes the importance of this figure, however, by showing that the effect of naturalization falls back to $7 \%$ and is no longer significant when length of stay is taken into account. More recently, Brastberg, Ragan and Nasir (2002) used panel data to estimate the impact of naturalization on employment and wage, by incorporating unobservables into the econometric model. They show that naturalization brings about a greater wage increase. In addition, their research findings show that the extent to which the naturalization wage premium is dependent on country of origin: immigrants from developing countries see their job status improve to a greater extent after gaining U.S. nationality than other immigrants. The same conclusion can be found in the article by DeVoretz and Pivnenko (2004) on the economic impact of gaining Canadian citizenship.

Unfortunately, the data set we use provides no information about individual wage levels. We focus therefore on measuring the impact of naturalization on immigrants' employment status. To do so, we estimate the probability of an immigrant for being employed at the end of the inter-census period by taking into account possible naturalization during this period, using different probit models whose parameter estimates are reported in Table B (see Appendices).

Within this framework, naturalization appears to have a positive impact on employment, even after taking into account education, age, gender, previous labor force status, size of place of residence and observation period. On average, gaining French nationality increases the probability of being employed at the end of the period by 2.7 points for men and 8.2 points for women. This means that the "naturalization premium” is much higher for women than for men, except amongst women from Western Europe, Portugal and Sub-Saharan Africa (Graphs 8 and 9, and Table 3). It is maximum amongst women from Turkey, followed by those from North Africa (naturalized Turkish women have an employment probability 26 points higher than the non-naturalized Turkish women, the same gap being 23 points for Tunisian women). Turkish women have the lowest employment rate. In other words, naturalization appears to have a very high impact on the labor force status of the most disadvantaged categories, i.e. those with the lowest employment probability. 

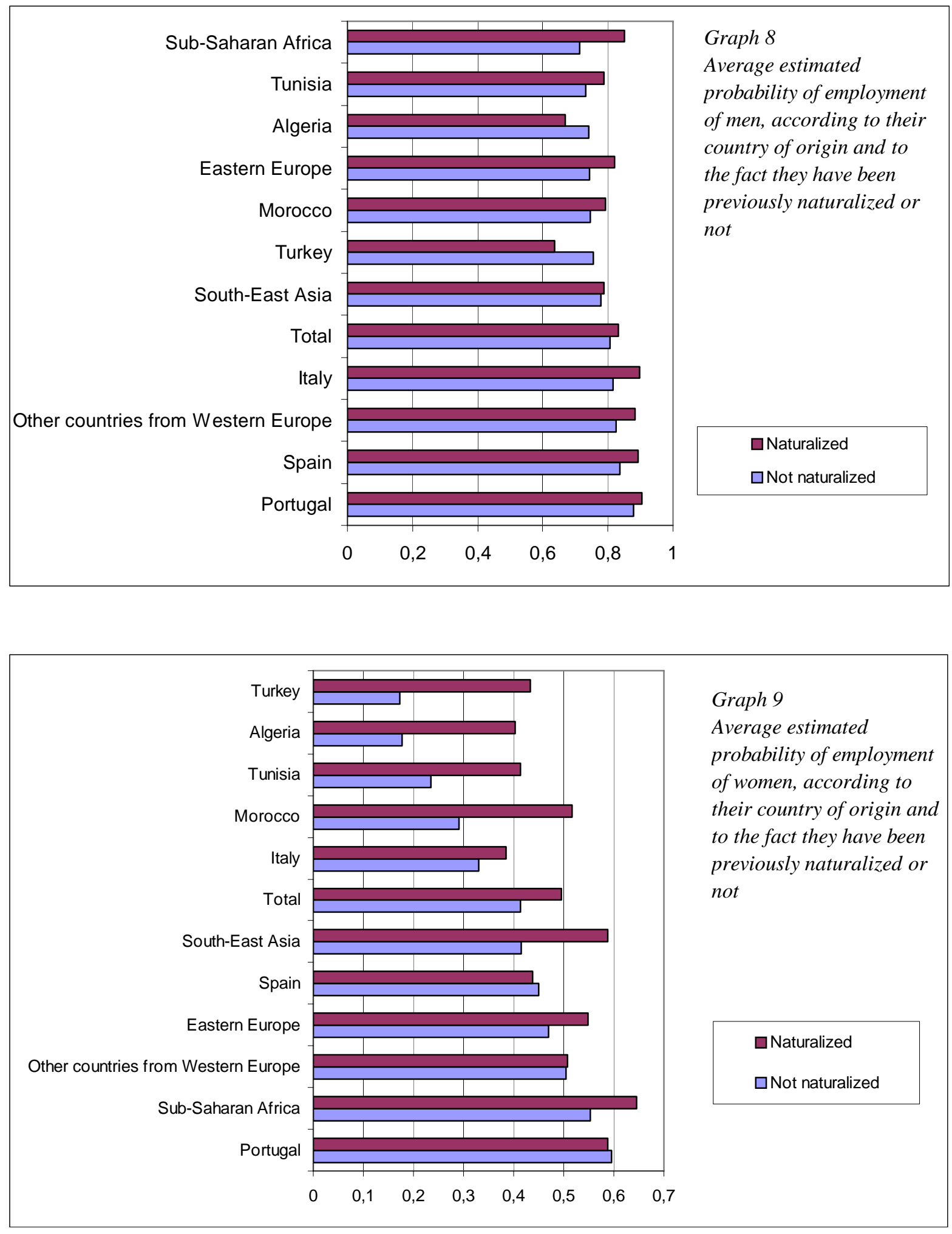

The effect of naturalization appears less prominent for men (Table 3). Gaining French citizenship actually lowers Algerian or Turkish men's employment probability. The highest "premium” is to be found amongst men from Sub-Saharan Africa, who also have a very low employment rate: naturalization increases their employment probability by 14 points. 
Table 3

Estimated marginal effect of naturalization on the
employment probability (univariate probit model)
\begin{tabular}{|l|r|r|}
\hline Country of origin & Men & Women \\
\hline Sub-Saharan Africa & 0,139 & 0,093 \\
\hline Italy & 0,082 & 0,055 \\
\hline Eastern Europe & 0,077 & 0,080 \\
\hline Other countries from & & \\
Western Europe & 0,059 & 0,003 \\
\hline Spain & 0,055 & $-0,011$ \\
\hline Tunisia & 0,055 & 0,226 \\
\hline Morocco & 0,048 & 0,225 \\
\hline Portugal & 0,027 & $-0,007$ \\
\hline South-East Asia & 0,011 & 0,174 \\
\hline Algeria & $-0,074$ & 0,180 \\
\hline Turkey & $-0,119$ & 0,261 \\
\hline Total & $\mathbf{0 , 0 2 7}$ & $\mathbf{0 , 0 8 2}$ \\
\hline
\end{tabular}

There exist major differences between men and women. While women's employment probability remains lower than that of men, male job activity reflects, above all, a decline in the macroeconomic situation over the period (and the rise of unemployment), whereas the steady growth of female employment probability is due to the increasingly sustained participation of women in the labor market. The model is probably better specified for men, as it omits two variables that have a major influence on female activity: the number of children and the spouse's labor force status, which were not collected at each census. Previous labor force status has a major influence on labor force status at the end of the period, even more so for women than for men. For both genders, non-employment is a greater impediment than unemployment.

Nonetheless, the positive impact of naturalization on employment can be due to some unobserved individual characteristics that affect significantly both processes. The magnitude of the impact measured by using a univariate probit model may thus be distorted by an endogeneity bias. It can be corrected by simultaneously estimating the probability of being naturalized between two censuses and the probability of having a job at the end of the inter-census period with a bivariate probit model. Parameter estimates of this model are reported in Table C (Appendices). ${ }^{12}$

Using this method, the impact of the various factors on gaining French nationality comes out almost unchanged, while their impact on the employment probability is markedly different: in particular, the effect of gaining nationality on employment probability increases sharply. We notice that the slope parameter associated with the naturalization indicator in the employment equation is generally much higher for men than for women. It varies significantly across countries. It is higher for migrants,

\footnotetext{
${ }^{12}$ Identification of this bivariate probit model is insured by restriction exclusions: the contextual covariates (i.e. the relative size of the community in the region of residence, the number of foreigners of the same origin in the département), are supposed to affect the probability of naturalization, and not the probability of employment at the end of the inter-census period. This assumption seems realistic because these covariates represent the local context seven or nine years before the immigrant's employment status is observed.
} 
especially men, coming from Southern Europe (Portugal, Italy, Spain) or from North Africa (Algeria, Tunisia) and Turkey. The increase in the effect of naturalization on the probability to be employed can be explained by the fact that the immigrants whose unobservable characteristics make them less employable are those who are the most likely to ask for naturalization, other observable things being equal. This interpretation is suggested by the negative sign of the estimated coefficient of correlation between the residuals of the two probit equations (see Table $\mathrm{C}$ in Appendices). This final result is in line with the hypothesis we set out at the very start, namely that gaining French nationality can help immigrants bring down some of the obstacles, in particular due to discrimination, that hinder their employability.

\section{Conclusions}

The probability of gaining French nationality varies significantly, depending on country of origin, gender, socio-professional category, educational attainment, marital status and size of the immigrant's place of residence. It decreases with the number of foreigners of the same national origin residing in the same local administrative area. However, and this is probably the newest finding, gaining French nationality significantly increases employability.

Many sociological studies have provided evidence that nationality of origin is a discriminating factor during the hiring process. The results obtained here show that gaining French nationality can significantly offset the extent of the said discrimination, at least in an environment where it is preceded by highly selective administrative procedures. By recognizing full citizenship to the immigrant aspiring to French nationality, the State greatly facilitates his or her integration into the labor market and society as a whole. 


\section{References}

AMADIEU, J.-F. (2004) : «Enquête Testing sur CV », Enquête réalisée pour l’Observatoire des Discriminations, mai 2004, Université Paris-I.

BARKAN, E.R. and KHOKHLOV, N. (1980) : "Socioeconomic Data as Indices of Naturalization Patterns in the United States: A Theory Revisited”, Ethnicity, 7 : 159-190.

BERTRAND, M. and MULLAINATHAN, S. (2004) : “Are Emily and Greg More Employable than Lakisha and Jamal? A Field Experiment on Labor Market Discrimination”, The American Economic Review, 94(4) : 159-190.

BELBAH, M. and CHATTOU, Z. (2001) : «Sujet et citoyen: évolutions, enjeux et significations de l'acquisition de la nationalité française par des marocains en France », Rapport de recherche pour le Ministère de l’Emploi et de la Solidarité, Paris.

BEVELANDER, P. and VEENMAN, J. (2006) : "Naturalisation and Socioeconomic Integration: The Case of the Netherlands”, IZA Discussion Paper No. 2153, Bonn.

BORREL, C. and DURR, J. M. (2005) : «Enquêtes annuelles de recensement : premiers résultats de la collecte 2004. Principales caractéristiques de la population et des logements ", Insee Première ${ }^{\circ}$ 1001, Paris.

BRATSBERG, B. , RAGAN, J. F., and NASIR, Z.M. (2002) : "The Effect of Naturalization on Wage Growth : A Panel Study of Young Male Immigrants”, Journal of Labor Economics, 20(3) : 268-597.

CHISWICK, B. (1978) : “The Effect of Americanization on the Earnings of Foreign-Born Men”, The Journal of Political Economy, 86(5) : 897-921.

CONSTANT, A., GATAUllinA, L., and ZIMMERMANN, K. F. (2008): "Naturalization Proclivities, Ethnicity and Integration”, CEPR Discussion Paper No. 6656, London.

DE SIPIO, L. (1987): “Social Science Literature and the Naturalization Process”, International Migration Review, 21(1) : 390-405.

DEVORETZ, D.J. and PIVNENKO, S. (2004) : "The Economic Causes and Consequences of Canadian Citizenship”, IZA Discussion Paper n 1395.

INSEE (2005), « Les immigrés en France », Collection Références, septembre.

MATH, A. and SPIRE, A. (1999) : «Des emplois réservés aux nationaux ? Dispositions légales et discriminations dans l'accès à l'emploi ", Informations Sociales, Droits des étrangers, ${ }^{\circ}{ }^{\circ} 7$. 
PORTES, A . and MOZO, R. (1985) : "The Political Adaptation Process of Cubans and Other Ethnic Minorities in the United States : A Preliminary Analysis”, International Migration Review, 19(1) : 3563.

PORTES, A. and CURTIS, J.W. (1987) : “Changing Flags : Naturalization and Its Determinants among Mexican Immigrants”, International Migration Review, 21(2) : 352-371.

SAYAD, A. (1982) : «La naturalization, les conditions sociales et sa signification chez les immigrés algériens », GRECO13, Migrations Internationales, 4-5.

SPIRE, A. (2005) : Etrangers à la carte : l'administration de l'immigration en France (1945-1975). Grasset, Paris.

SPIRE, A. and THAVE, S. (1999) : «Les acquisitions de la nationalité française depuis 1945 », in Regards sur l'immigration, Paris, INSEE, collection « Synthèse », n³0, Paris.

WEIL, P. (2002): Qu'est ce qu'un immigré? Histoire de la nationalité française depuis la Révolution, Grasset, Paris.

WEIL, P. (2005) : La République et sa diversité. Immigration, intégration, discriminations. Collection La République des idées, Le Seuil, Paris.

YANG, P. Q. (1994): “Explaining Immigrant Naturalization”, International Migration Review, 28(3) : 449-477. 


\section{APPENDICES}


Tableau A. Parameters of the naturalization equation (univariate probit models)

\begin{tabular}{|c|c|c|c|}
\hline Covariates & $\begin{array}{c}\text { Both } \\
\text { genders }\end{array}$ & Men & Women \\
\hline Intercept & $-1.011^{* * *}$ & $-1.017 * * *$ & $0.640 * * *$ \\
\hline \multicolumn{4}{|l|}{ Country of origin, Morocco } \\
\hline Algeria & $-0.575^{* * *}$ & $-0.761^{* * *}$ & $-0.373^{* * *}$ \\
\hline Spain & $-0.375^{* * *}$ & $-0.452^{* * *}$ & $-0.324 * * *$ \\
\hline Italy & $-0.483^{* * *}$ & $-0.542^{* * *}$ & $-0.466^{* * *}$ \\
\hline South-East Asia & $0.810 * * *$ & $0.649 * * *$ & $0.973^{* * *}$ \\
\hline Portugal & $0.670^{* * *}$ & $-0.739 * * *$ & $-0.624^{* * *}$ \\
\hline Tunisia & $-0.283^{* * *}$ & $-0.387 * * *$ & -0.174 \\
\hline Turkey & $-0.399 * * *$ & $-0.452^{* * *}$ & $-0.388 * * *$ \\
\hline Sub-Saharan Africa & $0.461^{* * *}$ & $0.356 * * *$ & $0.544^{* * *}$ \\
\hline Eastern Europe & $0.203^{* * *}$ & 0.130 & $0.247 * * *$ \\
\hline Western Europe & $-0.631^{* * *}$ & $-0.644^{* * *}$ & -0.658 \\
\hline \multicolumn{4}{|l|}{ Occupation Blue-collar } \\
\hline Farmers & $0.184^{*}$ & 0.079 & $0.430 * *$ \\
\hline Craftsman retail trader & $0.088^{*}$ & $0.102 *$ & -0.243 \\
\hline Manager & $0.287 * * *$ & $0.284 * * *$ & 0.165 \\
\hline Non working population & $-0.057 *$ & -0.017 & -0.053 \\
\hline Intermediate professions & $0.188 * * *$ & $0.209 * * *$ & 0.062 \\
\hline Unemployed & $0.135^{* * *}$ & $0.141 * * *$ & $0.104 *$ \\
\hline Office Worker & $0.178^{* * *}$ & $0.212^{* * *}$ & $0.135^{* * *}$ \\
\hline \multicolumn{4}{|l|}{ Education No diploma } \\
\hline Vocational High School & $0.403^{* * *}$ & $0.346^{* * *}$ & $0.494 * * *$ \\
\hline Junior High school & $0.254^{* * *}$ & $0.236^{* * *}$ & $0.261^{* * *}$ \\
\hline High-school and post-secondary education & $0.502^{* * *}$ & $0.464 * * *$ & $0.566^{* * *}$ \\
\hline \multicolumn{4}{|l|}{ Period 1968-1975 } \\
\hline $1975-1982$ & 0.017 & $-0.090 * *$ & $-0.113^{* *}$ \\
\hline $1982-1990$ & -0.047 & -0.049 & $-0.211 * * *$ \\
\hline 1990-1999 & $0.116^{* * *}$ & $0.154^{* * *}$ & $-0.092 *$ \\
\hline \multicolumn{4}{|l|}{ Arrival date in France, After 1982} \\
\hline Before 1968 & $-0.161^{* * *}$ & $-0.129^{* * *}$ & $-0.224^{* * *}$ \\
\hline Between 1968 and 1975 & $-0.294^{* * *}$ & $-0.264^{* * *}$ & $-0.366^{* * *} \mathrm{~s}$ \\
\hline Between 1975 and 1982 & $-0.146^{* * *}$ & -0.004 & $-0.302^{* * *}$ \\
\hline \multicolumn{4}{|l|}{$\underline{\text { Marital Status, Single }}$} \\
\hline Married & 0.015 & $0.078^{* *}$ & $-0.151^{* * *}$ \\
\hline Widowed or divorced & 0.071 & 0.061 & -0.005 \\
\hline \multicolumn{4}{|l|}{ Age, between 18 and 25 years old } \\
\hline Between 26 and 35 years old & 0.042 & $0.124^{* * *}$ & 0.020 \\
\hline Between 36 and 45 years old & $0.142^{* * *}$ & $0.232^{* * *}$ & $0.099 * *$ \\
\hline Between 46 and 55 years old & -0.004 & $0.120 * *$ & $-0.123^{* *}$ \\
\hline \multicolumn{4}{|l|}{ Contextual variables } \\
\hline $\begin{array}{l}\text { Relative size of the community in the region of } \\
\text { residence }\end{array}$ & $4.799 * * *$ & $4.954^{* * *}$ & $4.289 * * *$ \\
\hline Number of foreigners in the département & $-0.105^{* * *}$ & $-0.109 * * *$ & $-0.093^{* * *}$ \\
\hline $\begin{array}{l}\text { Number of foreigners of the same origin in the } \\
\text { département }\end{array}$ & $-0.261^{* * *}$ & $-0.223^{* * *}$ & $-0.272^{* * *}$ \\
\hline \multicolumn{4}{|l|}{ Gender Man } \\
\hline Woman & $0.175^{* * *}$ & & \\
\hline
\end{tabular}

Source : Echantillon Démographique Permanent, INSEE (1968-1999).

Remark: Statistical significance: $* * *=0.01 ; * *=0.05 ; *=0.10$. For each covariate, the reference value is written in italics. 


\section{Table B. Parameters of the employment equation (univariate probit models)}

\begin{tabular}{|c|c|c|c|c|c|}
\hline Covariates (model 1) & Sample & Covariates (model 2) & Both genders & Men & Women \\
\hline Intercept & $0.078 * *$ & Intercept & $0.911^{* * *}$ & $1.460 * * *$ & -0.170 \\
\hline \multicolumn{6}{|l|}{ Not naturalized (ref.) } \\
\hline Naturalized & $0.161^{* * *}$ & Country of origin* naturalization & & & \\
\hline Country of origin, & & Morocco, non naturalized (ref.) & & & \\
\hline Morocco (ref.) & & $\overline{\text { Morocco, naturalized }}$ & $0.264^{* *}$ & 0.183 & $0.360 * *$ \\
\hline$\overline{\text { Sub-Saharan Africa }}$ & $0.361^{* * *}$ & Spain, non naturalized & $0.293^{* * *}$ & $0.242 * * *$ & $0.423 * * *$ \\
\hline Algeria & 0.054 & Spain, naturalized & $0.379 * * *$ & $0.410 * * *$ & $0.498 * * *$ \\
\hline South-East Asia & $0.301 * * *$ & Eastern Europe, non naturalized & 0.074 & -0.060 & $0.314^{* * *}$ \\
\hline Spain & $0.333^{* * *}$ & Eastern Europe, naturalized & $0.272^{* * *}$ & 0.164 & $0.422 * * *$ \\
\hline Eastern Europe & $0.265^{* * *}$ & Sub-Saharan Africa, non naturalized & $0.196 * *$ & -0.050 & $0.480 * * *$ \\
\hline Italy & $0.277 * * *$ & Sub-Saharan Africa, naturalized & $0.423^{* * *}$ & $0.390 * *$ & $0.460 * * *$ \\
\hline Portugal & $0.590 * * *$ & Algeria, non naturalized & 0.011 & 0.065 & $-0.143^{*}$ \\
\hline Tunisia & $0.102^{* *}$ & Algeria, naturalized & 0.071 & -0.029 & 0.186 \\
\hline \multirow[t]{32}{*}{ Turkey } & -0.011 & South-East Asia, non naturalized & $0.226 * * *$ & $0.332^{* * *}$ & 0.071 \\
\hline & & South-East Asia, naturalized & $0.321 * * *$ & $0.251^{*}$ & $0.427 * * *$ \\
\hline & & Western Europe, non naturalized & $0.216 * * *$ & $0.166^{*}$ & $0.251 * * *$ \\
\hline & & Western Europe, naturalized & $0.226^{*}$ & 0.264 & $0.284^{*}$ \\
\hline & & Italy, non naturalized & $0.147 * * *$ & $0.141^{*}$ & $0.212^{* * *}$ \\
\hline & & Italy, naturalized & $0.285^{* * *}$ & $0.421 * * *$ & $0.272 * *$ \\
\hline & & Portugal, non naturalized & $0.564 * * *$ & $0.504 * * *$ & $0.657 * * *$ \\
\hline & & Portugal, naturalized & $0.576 * * *$ & $0.708 * * *$ & $0.561 * * *$ \\
\hline & & Tunisia, non naturalized & 0.0001 & 0.023 & -0.024 \\
\hline & & Tunisia, naturalized & 0.148 & $0.231 *$ & 0.159 \\
\hline & & Turkey, non naturalized & 0.015 & 0.115 & $-0.212^{* *}$ \\
\hline & & Turkey, naturalized & 0.012 & -0.224 & $0.429 *$ \\
\hline & & Previous employement status Employed & & & \\
\hline & & Unemployed & $-0.703 * * *$ & $-0.651 * * *$ & $-0.757 * * *$ \\
\hline & & Out of the labor force & $-1.284^{* * *}$ & $-0.991 * * *$ & $-1.217 * * *$ \\
\hline & & Time period, $1968-1975$ & & & \\
\hline & & $1975-1982$ & $-0.178 * * *$ & $-0.398 * * *$ & $0.086^{* *}$ \\
\hline & & $1982-1990$ & $-0.307 * * *$ & $-0.610 * * *$ & $0.113 * * *$ \\
\hline & & 1990-1999 & $-0.403 * * *$ & $-0.840^{* * * *}$ & $0.169 * * *$ \\
\hline & & Education No diploma & & & \\
\hline & & Junior high & $0.279 * * *$ & $0.274 * * *$ & $0.284 * * *$ \\
\hline & & Vocational high & $0.144^{* * *}$ & $0.127 * * *$ & $0.182^{* * *}$ \\
\hline & & High & $0.371^{* * *}$ & $0.410 * * *$ & $0.366^{* * *}$ \\
\hline & & Age, Between 18 and 25 years old & & & \\
\hline & & Between 26 and 35 years old & 0.118 & -0.003 & 0.110 \\
\hline & & Between 36 and 45 years old & $0.249 * *$ & -0.048 & $0.309 * *$ \\
\hline & & Between 46 and 55 years old & -0.159 & $-0.632^{* * *}$ & 0.118 \\
\hline & & Marital status Single & & & \\
\hline & & Married & -0.018 & $0.179 * * *$ & $-0.130 * * *$ \\
\hline & & Widowed or divorced & 0.0089 & -0.024 & -0.016 \\
\hline & & $\underline{\text { Gender Man }}$ & & & \\
\hline & & Woman & $-0.530 * * *$ & & \\
\hline
\end{tabular}

Source: Echantillon Démographique Permanent, INSEE (1968-1999).

Remarks : Statistical significance $: * * *=0.01 ; * *=0.05 ; *=0.10$. For each covariate, the reference value is written in italics. 
Table C. Parameter estimates of the bivariate probit model

\begin{tabular}{|c|c|c|c|c|c|}
\hline \multicolumn{3}{|c|}{ Naturalization equation } & \multicolumn{3}{|c|}{ Employment equation } \\
\hline Covariates & Men & Women & Covariates & Men & Women \\
\hline Intercept & $-1.109 * * *$ & $-0.678^{*}$ & & $0.933^{* * *}$ & $-0.346^{* *}$ \\
\hline Country of origin, Morocco & & & & & \\
\hline Sub-Saharan Africa & $0.274 * * *$ & $0.531^{* * *}$ & & & \\
\hline Algeria & $-0.720 * * *$ & $-0.371^{* * *}$ & Country of origin*naturalization & & \\
\hline South-East Asia & $0.563 * * *$ & $0.967 * * *$ & Morocco, non naturalized & & \\
\hline Spain & $-0.371^{* * *}$ & $-0.329 * * *$ & Morocco, naturalized & $1.494 * * *$ & $0.928 * * *$ \\
\hline Eastern Europe & -0.114 & $-0.239 * * *$ & Spain, non naturalized & $0.386 * * *$ & $0.460 * * *$ \\
\hline Italy & $-0.448^{* * *}$ & $-0.460 * * *$ & Spain, naturalized & $1.904 * * *$ & $1.159 * * *$ \\
\hline Portugal & $-0.719 * * *$ & $-0.627 * * *$ & Eastern Europe, non naturalized & 0.002 & $0.307 * * *$ \\
\hline Tunisia & $-0.528^{* *}$ & $-0.324 * * *$ & Eastern Europe, naturalized & $1.516 * * *$ & $0.972^{* * *}$ \\
\hline Turkey & $-0.550 * * *$ & $-0.392 * * *$ & Sub-Saharan Africa, non naturalized & -0.089 & $0.414^{* * *}$ \\
\hline Western Europe & $-0.594 * *$ & 0.033 & Sub-Saharan Africa, naturalized & $1.579 * * *$ & $0.938 * * *$ \\
\hline & & & Algeria, non naturalized & $0.331^{* * *}$ & -0.096 \\
\hline & & & Algeria, naturalized & $1.890 * * *$ & $0.874 * * *$ \\
\hline & & & South-East Asia, non naturalized & 0.039 & -0.051 \\
\hline & & & South-East Asia, naturalized & $1.325 * * *$ & $0.818^{* * *}$ \\
\hline & & & Western Europe, non naturalized & $0.457 * * *$ & $0.354 * * *$ \\
\hline & & & Western Europe, naturalized & $1.979 * * *$ & $1.056 * * *$ \\
\hline & & & Italy, non naturalized & $0.346 * * *$ & $0.270 * * *$ \\
\hline & & & Italy, naturalized & $1.961 * * *$ & $0.976 * * *$ \\
\hline & & & Portugal, non naturalized & $0.721 * * *$ & $0.718 * * *$ \\
\hline & & & Portugal, naturalized & $2.372 * * *$ & $1.316^{* * *}$ \\
\hline & & & Tunisia, non naturalized & $0.151 * *$ & -0.005 \\
\hline & & & Tunisia, naturalized & $1.781^{* * *}$ & $0.787 * *$ \\
\hline & & & Turkey, non naturalized & $0.357 * * *$ & -0.152 \\
\hline & & & Turkey, naturalized & $1.706^{* * *}$ & $1.181^{* * *}$ \\
\hline Age, Between 18 and 25 years old & & & Age, Between 18 and 25 years old & & \\
\hline Between 26 and 35 years old & $0.105^{* *}$ & -0.033 & Between 26 and 35 years old & -0.022 & 0.112 \\
\hline Between 36 and 45 years old & $0.298 * * *$ & 0.138 & Between 36 and 45 years old & -0.115 & $0.303 * *$ \\
\hline Between 46 and 55 years old & $-0.104^{* * *}$ & $-0.143^{* * *}$ & Between 45 and 55 years old & $-0.568^{* * *}$ & 0.118 \\
\hline Occupation blue collar & & & & & \\
\hline Farmers & $0.128 * *$ & $0.423^{* *}$ & Education No diploma & & \\
\hline Craftsman retail trader & $0.165^{* * *}$ & -0.250 & Junior High school & 0.022 & $0.149 * * *$ \\
\hline Manager & $0.334 * * *$ & 0.214 & Vocational High School & $0.089 * * *$ & $0.209 * * *$ \\
\hline Non working population & -0.027 & -0.036 & High-school and post-secondary & $0.091 * *$ & $0.275^{* * *}$ \\
\hline Intermediate professions & $0.265^{* * *}$ & 0.121 & education & & \\
\hline Unemployed & $0.171^{* * *}$ & $0.119 * *$ & & & \\
\hline Office Worker & $0.139 * * *$ & $0.158^{* * *}$ & & & \\
\hline Time period, $1968-1975$ & & & Time period, $1968-1975$ & & \\
\hline $1975-1982$ & $-0.101 * * *$ & $-0.227 * * *$ & $1975-1982$ & $-0.250^{* * *}$ & $0.113^{* * *}$ \\
\hline $1982-1990$ & $0.111^{* * *}$ & $-0.369 * * *$ & $1982-1990$ & $-0.385^{* * *}$ & $0.157 * * *$ \\
\hline 1990-1999 & 0.027 & $-0.316^{* *}$ & 1990-1999 & $-0.652^{* * *}$ & $0.207 * * *$ \\
\hline Education No diploma & & & Marital status, Single & & \\
\hline Junior High school & & & Married & $0.098 * * *$ & $-0.103^{* * *}$ \\
\hline Vocational High School & $0.204 * * *$ & $0.261^{* * *}$ & Widowed or divorced & -0.059 & -0.006 \\
\hline High-school and post-secondary & $0.264 * * *$ & $0.493^{* * *}$ & & & \\
\hline education & $0.348^{* * *}$ & $0.544^{* * *}$ & Previous employment status & & \\
\hline Marital status, Single & & & Employed & & \\
\hline Married & $0.090 * * *$ & $-0.151^{* * *}$ & Unemployed & $-0.570 * * *$ & $-0.747 * * *$ \\
\hline Widowed or divorced & 0.072 & -0.006 & Out of the labor force & $-0.795^{* * *}$ & $-1.178^{* * *}$ \\
\hline $\begin{array}{l}\text { Number of foreigners in the département } \\
\text { Relative size of the community in the } \\
\text { region of residence }\end{array}$ & $-0.044^{* * *}$ & $-0.078^{* * *}$ & & & \\
\hline
\end{tabular}

Source: Echantillon Démographique Permanent, INSEE (1968-1999)

Remarks : Statistical significance : $* * *=0.01 ; * *=0.05 ; *=0.10$. For each covariate, the reference value is written in italics. 